\title{
Biomarkers of Oxidative Stress and Acetylcholinesterase Activity in the Blood of Grass Snake (Natrix natrix L.) during Prehibernation and Posthibernation Periods
}

\author{
Jelena Gavrić*, Marko Prokić, Svetlana Despotović, Branka Gavrilović, Tijana \\ Radovanović, Slavica Borković-Mitić, Slađan Pavlović and Zorica Saičić \\ Department of Physiology; Institute for Biological Research "Siniša Stanković"; University of Belgrade - Serbia
}

\begin{abstract}
This work examined the enzymatic (superoxide dismutase-CuZn SOD, catalase-CAT, glutathione peroxidase-GSH$P x$, glutathione reductase-GR, and the biotransformation phase II enzyme glutathione-S-transferase-GST) and nonenzymatic (total glutathione-GSH and lipid peroxides-TBARS concentrations) biomarkers of oxidative stress and acetylcholinesterase (AChE) activity in the blood of the grass snake (Natrix natrix L.) during prehibernation and posthibernation. The animals were collected in October (prehibernation) and April (posthibernation) at the nature reserve Obedska Bara $(O B)$ and industrial region Pančevački Rit (PR) in Serbia. In posthibernation, decreased CAT activity and TBARS concentration in specimens from PR, and decreased GR and AChE activities, and TBARS concentration in specimens from $O B$ were observed, whereas GR and GST activities and GSH concentration were significantly elevated in the specimens from PR. In prehibernation, CAT activity and GSH concentration were increased, while GSH-Px, GR, GST and AChE activities and TBARS concentration were decreased in the specimens from PR when compared to animals from OB. During the posthibernation, the activity of CuZn SOD was decreased, while GST and AChE activities were increased in the specimens from PR when compared to the specimens from $O B$. These differences represented an adaptive mechanism to oxidative stress induced by tissue reoxygenation during arousal from hibernation and could be modulated by environmental pollution.
\end{abstract}

Key words: Grass snake, oxidative stress, hibernation, acetylcholinesterase, antioxidant enzymes

\section{INTRODUCTION}

Reactive oxygen species (ROS) are the products of aerobic metabolism that have physiological roles at low concentrations. Oxidative stress occurs when the production of ROS exceeds the capacity of enzymatic and non-enzymatic antioxidants. Overproduction of ROS has deleterious effects as they can lead to damage of cell structures, proteins, DNA and lipids (Valko et al. 2007). Oxidative stress can occur during normal physiological activities such as exercise, arousal from hibernation, starvation, etc.
(Bagnyukova et al. 2003). ROS can be also produced intracellularly by different xenobiotics that exist in the environment and due to the status of antioxidant that give information about the ability to resist environmental stress (Pavlović et al. 2010; Messina et al. 2014). In addition, some pharmaceutical products can also be found in aquatic ecosystems and affect the antioxidant defense system of aquatic organisms (Bartoskova et al. 2013). Components of the antioxidant system serve to neutralize the deleterious effects of ROS. The principal components of this system are the antioxidant enzymes, superoxide dismutase

*Author for correspondence: jelena.gavric@ibiss.bg.ac.rs 
(SOD), catalase (CAT), glutathione peroxidase (GSH-Px), glutathione reductase (GR), and the biotransformation phase II enzyme glutathione-Stransferase (GST) (Van der Oost et al. 2003).

Glutathione (GSH), the nonenzymatic component of the antioxidant system, plays a key role in the cellular defence and serves as a reservoir for the amino acid cysteine. Mitochondrial GSH depletion leads to cell death and could ultimately determine cell vulnerability to oxidant attack (Kovačević et al. 2008). Lipid peroxidation results from the oxidation of polyunsaturated fatty acids during oxidative stress and the concentrations of lipid peroxides are reliable biomarkers of oxidative stress (Van der Oost et al. 2003). Among numerous biomarkers used in environmental studies, acetylcholinesterase activity (AChE) is commonly used to assess the neurotoxicity (Durieux et al. 2011).

Metabolic rate depression is an adaptive strategy of hibernation that extends the survival time of animals, supporting months or even years of dormancy (Storey and Storey 1990). However, arousal from hibernation stimulates respiration and can cause oxidative stress (Banyukova et al. 2003). Therefore, antioxidant defences are important during the increased tissue oxygenation. Organisms use strict genetic control mechanisms to overcome these physiological extremes (Andrews 2007). Hibernators must maintain metabolic homeostasis at a very low body temperature and then return to a state that requires increased oxygen consumption and is associated with ROS generation. Hermes-Lima and Storey (1993) observed an increase in total antioxidant capacity during physiological stress of anoxia and freezing of snake species Thamnophis sirtalis parietalis. They suggested that the antioxidant system was an important part of the biochemical machinery that allowed the survival under anoxic or freezing conditions.

Contrary to the mammals, hibernation in reptiles has been studied to a lesser extent. Low winter temperatures are thermally challenging for ectothermal species such as snakes. Most temperate zone snakes spend unfavorable weather conditions during the winter in the hibernaculum, underground shelters, where they remain inactive (Bauwens 1981). Photoperiod and temperature changes affect the endocrine glands and are critical factors that regulate hibernation. According to Thapliyal and Sharan (1980), $\mathrm{O}_{2}$ uptake by the brain is related to initiation, maintenance and termination of hibernation in the water snake Natrix piscator.

$N$. natrix L. is a semi-aquatic, medium-sized, oviparous, diurnal snake with a range that extends from extreme northern Africa to near the Artic Circle in Scandinavia (Gregory and Isaac 2004). Hibernation of $N$. natrix usually begins in October and lasts until April. They begin to hibernate when the environmental temperature drops below $6^{\circ} \mathrm{C}$ for several days. Water snakes are important components of ecosystems that use both aquatic and terrestrial resources. They are long-lived organisms at the top of the food chain. These features render them potential bioindicator species. Campbell and Campbell (2001) reported that snakes were generally ignored in ecological risk assessment studies and that they were the least studied group of vertebrates regarding environmental contaminants (Hopkins 2000).

The aim of the present study was to compare the expression of selected markers of oxidative stress and neurotoxicity in the blood of the grass snake $N$. natrix during the periods of prehibernation and posthibernation. Investigations were made for the enzymatic (superoxide dismutase-CuZnSOD, catalase-CAT, glutathione peroxidase-GSH-Px, glutathione reductase-GR, and the biotransformation phase II enzyme glutathione-Stransferase-GST), and nonenzymatic (total glutathione-GSH and lipid peroxides-TBARS concentrations) biomarkers of oxidative stress, as well as the biomarker of neurotoxicity, acetylcholinesterase (AChE) activity in the blood of snake during prehibernation (October) and posthibernation (April) periods in the specimens from two localities: nature reserve Obedska Bara $(\mathrm{OB})$ and industrial region Pančevački Rit (PR). The study also established possible modulation of investigated blood parameters in respect to environmental conditions.

\section{MATERIAL AND METHODS}

\section{Site description and sample collection}

Female specimens of the grass snake species $N$. natrix were caught manually in autumn (late October - prehibernation period) and spring (April - posthibernation period) at two localities: Obedska bara (OB) and Pančevački rit (PR), (Fig. 1). In late October, the snakes cease to feed, became lethargic and were ready to hibernate. Ten healthy adult females were caught at $\mathrm{OB}$ and 10 
were caught at PR in late October, while five and nine specimens were caught at $\mathrm{OB}$ and $\mathrm{PR}$ in April, respectively. Animal capture was approved by the Serbian Ministry for Energy, Development and Environmental Protection (Permissions Nos: 353-01-640/2012-03 and 353-01-77/2013-08). The animals were handled in accordance with the guidelines of the Animal Welfare Act of the Republic of Serbia.

The nature reserve Obedska Bara (OB) $\left(44^{\circ} 44.8^{\prime} 08.37^{\prime \prime} \mathrm{N} ; 1^{\circ} 59^{\prime} 14.38^{\prime \prime} \mathrm{E}\right)$ is one of the oldest protected areas in the world (since 1874). OB contains the abandoned bed of the Sava River that flows more southward. OB has been registered as a nature reserve by the Ramsar Convention on wetlands since 1977 . This locality includes areas of special significance for birds of Europe. OB is linked to the Sava River only when water levels rise. Pančevački Rit (PR) $\left(44^{\circ} 50^{\prime} 01.68^{\prime \prime} \mathrm{N} ; 20^{\circ} 29^{\prime} 48.43^{\prime \prime} \mathrm{E}\right)$ is located in the southwestern part of Banat near Belgrade, between the rivers Danube and Tamiš. In the past, it was a wetland area often flooded by the Danube and Tamiš. Today it is a suburban region exposed to increased anthropogenic pressure, receiving extensive industrial and urban waste discharges. Consequently, it was exposed to a variety of pollutants communal and industrial waste from a factory for glue production, cattle fodder, dairy farm, sugar refinery, abattoir, glass and chemical industries and the Pančevo oil refinery.

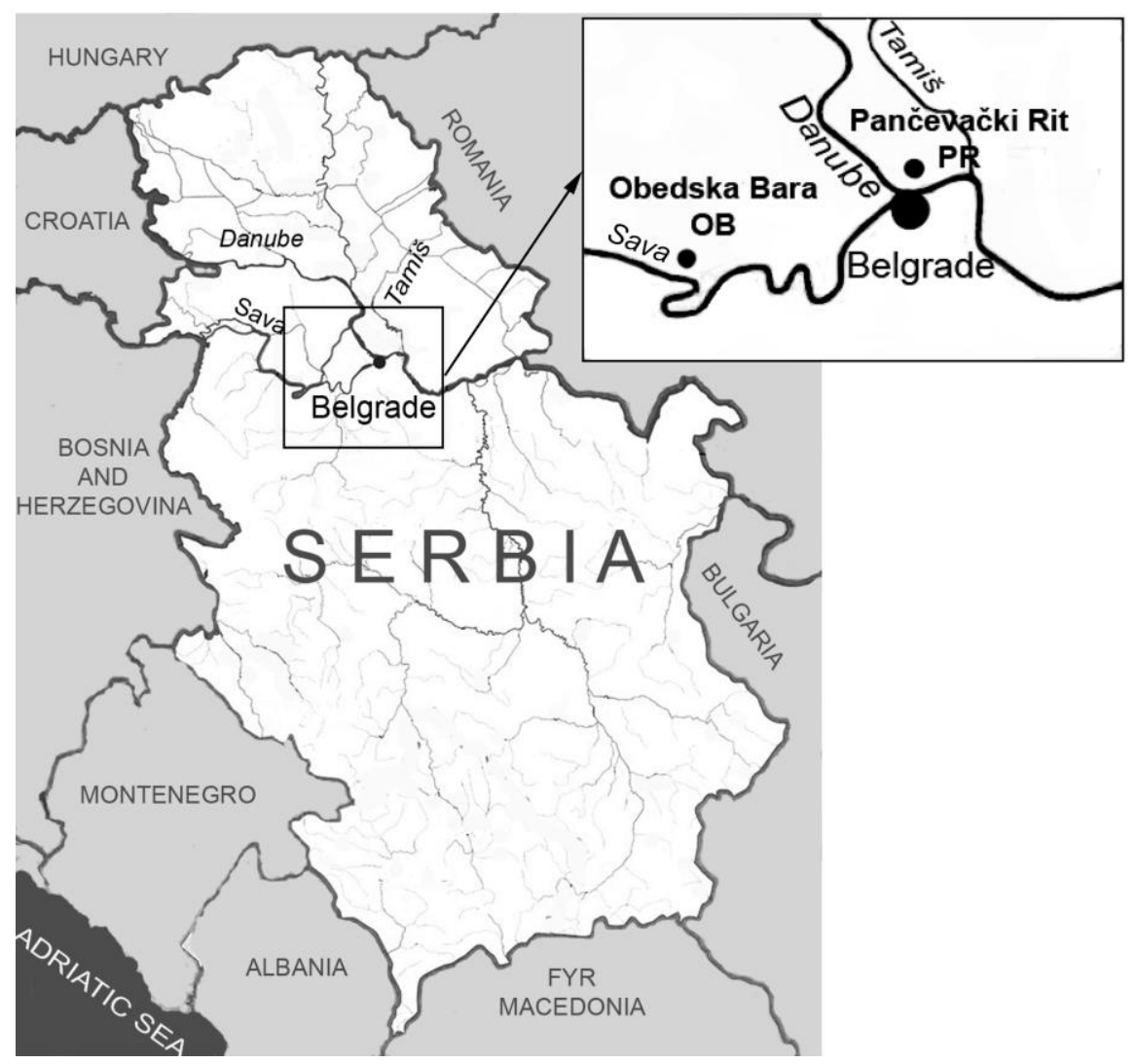

Figure 1 - The geographical positions of the investigated localities, Obedska Bara (OB) and Pančevački Rit (PR) in Serbia.

\section{Biochemical analysis}

After decapitation, blood was immediately collected in heparinized test tubes $(5000 \mathrm{U} / \mathrm{mL}$ heparin). Biomarkers of oxidative stress were assessed immediately after blood collection in order to avoid any possible modification of the results caused due to storage (Fazio et al. 2014).
Lipid peroxidation was measured by the thiobarbituric acid (TBA) reaction according to the method of Ohkawa et al. (1979). Red-color was produced by the reaction of TBA with malondialdehyde (MDA) and was measured at 532 $\mathrm{nm}$. The results were expressed as nmol TBARS/mL blood. 
To separate the plasma from the blood cells, fresh blood was centrifuged at $5000 \mathrm{rpm}$ for $15 \mathrm{~min}$. Plasma samples were used for GSH determination according to the method of Griffith (1980) and expressed as nmol/L plasma. GST activity towards 1-chloro-2,4-dinitrobenzene (CDNB) as a substrate was measured as described by Habig et al. (1974). One unit of GST activity was defined as $\mathrm{nmol} \mathrm{GSH} / \mathrm{min} / \mathrm{mL}$ of plasma. AChE activity was determined in the plasma according to Ellman et al. (1961) by measuring the continuous reaction of thiol with 5,5-dithiobis-(2-nitrobenzoic acid) DTNB. The product formed in the reaction was yellow 5-thio-2-nitrobenzoate (TNB) and was detected spectrophotometrically at $412 \mathrm{~nm}$. AChE activity was expressed as $\mu \mathrm{mol} / \mathrm{min} / \mathrm{L}$ plasma.

Isolated red blood cells (RBCs) were washed three times with three volumes of $0.65 \% \mathrm{NaCl}$. The hemoglobin $(\mathrm{Hb})$ concentration in erythrocytes $(\mathrm{g}$ $\mathrm{Hb} / 100 \mathrm{~mL})$ was estimated by the cyanmethemoglobin method (Drabkin and Austin 1935). CuZn SOD activity was measured in the hemolysates of washed RBCs from which $\mathrm{Hb}$ was previously removed by the method of Tsuchihashi (1923). CuZn SOD activity was measured by the epinephrine method (Misra and Fridovich 1972), based on the capacity of SOD to inhibit autoxidation of adrenaline to adrenochrome. One unit of SOD activity was defined as the amount of enzyme that caused 50\% inhibition of the autoxidation of adrenaline.

CAT activity was determined according to Claiborne (1984) and expressed as $\mu \mathrm{mol}$ $\mathrm{H}_{2} \mathrm{O}_{2} / \mathrm{min} / \mathrm{g} \mathrm{Hb}$. The method is based on $\mathrm{H}_{2} \mathrm{O}_{2}$ degradation by CAT contained in the examined samples. In this procedure, $30 \mathrm{mM} \mathrm{H}_{2} \mathrm{O}_{2}$ served as the substrate. According to McCord and Fridovich (1969), hemolysates containing about $50 \mathrm{~g} \mathrm{Hb} / \mathrm{L}$ were used for the determination of GSH-Px activities (Maral et al. 1977). The assay was based on the measurement of oxidation of nicotine amide dinucleotide phosphate (NADPH) at $340 \mathrm{~nm}$, with t-buthyl-hydroperoxide as substrate and the activity was expressed as nmol NADPH/min/g Hb. The activity of GR was estimated by measuring the NADPH oxidation at $340 \mathrm{~nm}$ in the presence of oxidized glutathione (Glatzle et al. 1974) and expressed as nmol NADPH/min/g Hb. The method is based on the ability of GR to catalyze the reduction of oxidized glutathione (GSSG) to reduced glutathione (GSH), using NADPH as substrate in phosphate buffer $(\mathrm{pH}$ 7.4). The activities of antioxidant defence enzymes were measured using a Shimadzu UV-160 spectrophotometer with a temperature-controlled cuvette holder. All chemicals were obtained from Sigma-Aldrich (St Louis, MO, USA).

\section{Statistical analysis}

The data have been expressed as the means \pm Standard Error (S.E.). Significant differences between the samples were determined by the nonparametric Mann-Whitney U-test. The minimum significance level was $\mathrm{p}<0.05$. Principal component analysis (PCA) served to detect the variables that significantly contributed to the differences of the investigated parameters during the pre- and posthibernation periods and at different localities. Analytical protocols described by Darlington et al. (1973) and Dinneen and Blakesley (1973) were used.

\section{RESULTS}

Snout-vent length (SVL) and body weight of the grass snakes from the $\mathrm{OB}$ and $\mathrm{PR}$ are given in Table 1. The hemoglobin concentration in the blood of the grass snake $N$. natrix from the two investigated localities is presented in Table 2 . The hemoglobin concentration was significantly lower during the posthibernation period at both the localities $(\mathrm{p}<0.05)$.

Table 1 - Snout-vent length $(\mathrm{cm})$ and body weight $(\mathrm{g})$ of the grass snake (Natrix natrix) during the prehibernation and posthibernation periods. Data are expressed as the mean \pm standard error of the mean.

\begin{tabular}{llcc}
\hline & & Prehibernation & Posthibernation \\
\hline $\mathrm{SVL}^{1}(\mathrm{~cm})$ & $\mathrm{OB}^{2}$ & $78.36 \pm 1.94$ & $73.20 \pm 4.35$ \\
& $\mathrm{PR}^{3}$ & $75.39 \pm 0.92$ & $73.28 \pm 1.72$ \\
\hline Body weight $(\mathrm{g})$ & $\mathrm{OB}$ & $209.26 \pm 13.07$ & $149.38 \pm 24.84$ \\
& $\mathrm{PR}$ & $157.32 \pm 6.33$ & $138.12 \pm 10.02$ \\
\hline
\end{tabular}

Note: ${ }^{1} \mathrm{SVL}=$ snout-vent length, ${ }^{2} \mathrm{OB}=$ Obedska bara, ${ }^{3} \mathrm{PR}=$ Pančevački rit

Table 2 - The concentration of hemoglobin $(\mathrm{g} / 100 \mathrm{~mL})$ in the blood of the grass snake (Natrix natrix) during the prehibernation and posthibernation periods. Data are expressed as the mean \pm standard error of the mean.

$* \mathrm{p}<0.05$ represents a minimal significant level.

\begin{tabular}{lll}
\hline & \multicolumn{1}{c}{$\mathbf{O B}^{\mathbf{1}}$} & $\mathbf{P R}^{\mathbf{2}}$ \\
\hline Prehibernation & $5.44 \pm 0.41$ & $6.37 \pm 0.43$ \\
\hline Posthibernation & $3.65 \pm 0.49 *$ & $4.73 \pm 0.29 *$ \\
\hline Note: ${ }^{1} \mathrm{OB}=$ Obedska bara, ${ }^{2} \mathrm{PR}=$ Pančevački rit
\end{tabular}


The activity of CuZn SOD (Fig. 2A) was significantly decreased during the posthibernation period at PR $(\mathrm{p}<0.05)$, while no differences between localites were detected during the prehibernation period. During the prehibernation period, the activity of CAT (Fig. 2B) was significantly higher in the blood of the snakes collected from the PR as compared to the snakes from OB $(p<0.05)$. Significant differences between the localities were not observed during the posthibernation period. At the same time, the activity of CAT in the snakes from the PR during the posthibernation period was significantly lower than during the prehibernation period $(\mathrm{p}<0.05)$. The activity of GSH-Px (Fig. 2C) during the prehibernation period was markedly lower at PR when compared to $\mathrm{OB}(\mathrm{p}<0.05)$.

In the snakes from OB, GR activity (Fig. 2D) was significantly lower during the posthibernation period when compared to the prehibernation period $(p<0.05)$. However, the activity of GR from snakes caught in the PR was significantly decreased during the prehibernation period in comparison to the posthibernation period $(\mathrm{p}<0.05)$.

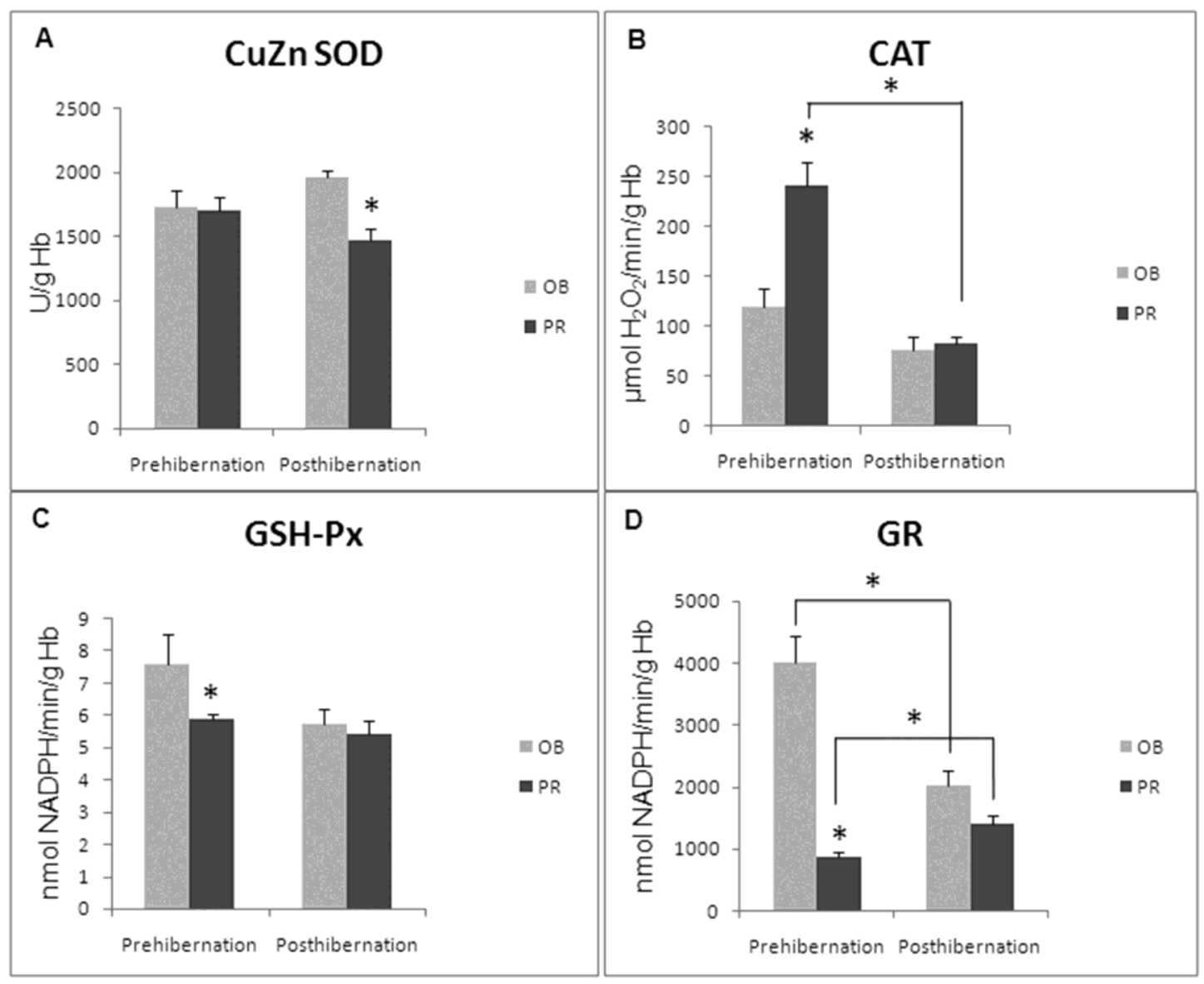

Figure 2 - The activities of: A) copper zinc containing superoxide dismutase (CuZn SOD); B) catalase (CAT); C) glutathione peroxidase (GSH-Px); D) glutathione reductase (GR) in red blood cells (RBCs) of the grass snake (Natrix natrix) from Obedska Bara (OB) and Pančevački Rit (PR) during the prehibernation and posthibernation periods. Specific enzyme activities are expressed as U/g hemoglobin $(\mathrm{Hb})$. Significant differences between the means were established by the non-parametric Mann-Whitney U-test. * $\mathrm{p}<0.05$ represents a minimal significant level.

Before hibernation, GR activity was markedly elevated in the snakes from $\mathrm{OB}$ as compared to snakes from PR $(p<0.05)$. The activity of GST (Fig. 3A) during posthiberanation was higher in the snakes from the PR than during the prehibernation period $(\mathrm{p}<0.05)$. Before hibernation, GST activity was significantly decreased in the snakes from the PR as compared 
to the snakes from OB $(\mathrm{p}<0.05)$. After hibernation, GST was increased in the snakes from the PR as compared to the snakes from OB $(\mathrm{p}<0.05)$.

The concentration of GSH (Fig. 3B) in the plasma was significantly increased in the snakes from the PR during the posthibernation period than during the prehibernation period $(\mathrm{p}<0.05)$. GSH was markedly increased in the snakes from the PR when compared to the snakes from $\mathrm{OB}$ during both the periods $(\mathrm{p}<0.05)$. At both the localities, the concentration of lipid peroxides, expressed as the TBARS blood concentration (Fig. 3C), was significantly decreased after hibernation $(\mathrm{p}<0.05)$. At the same time, during the prehibernation period, TBARS was significantly decreased in the snakes from the PR when compared those from OB ( $\mathrm{p}<0.05)$. Plasma AChE activity in the snakes from OB (Fig. 3D) was lower in the snakes during posthibernation $(\mathrm{p}<0.05)$. Before hibernation, the activity of AChE was significantly decreased in the snakes from the PR in comparison to snakes from OB. After hibernation the opposite result was obtained.

Figure 4 shows PCA of all of the investigated parameters during the prehibernation and posthibernation periods in snakes from both sites. The data showed separation of the two investigated sampling localities during prehibernation and posthibernation (Factor 1:46.18\% and Factor 2:34.57\%).

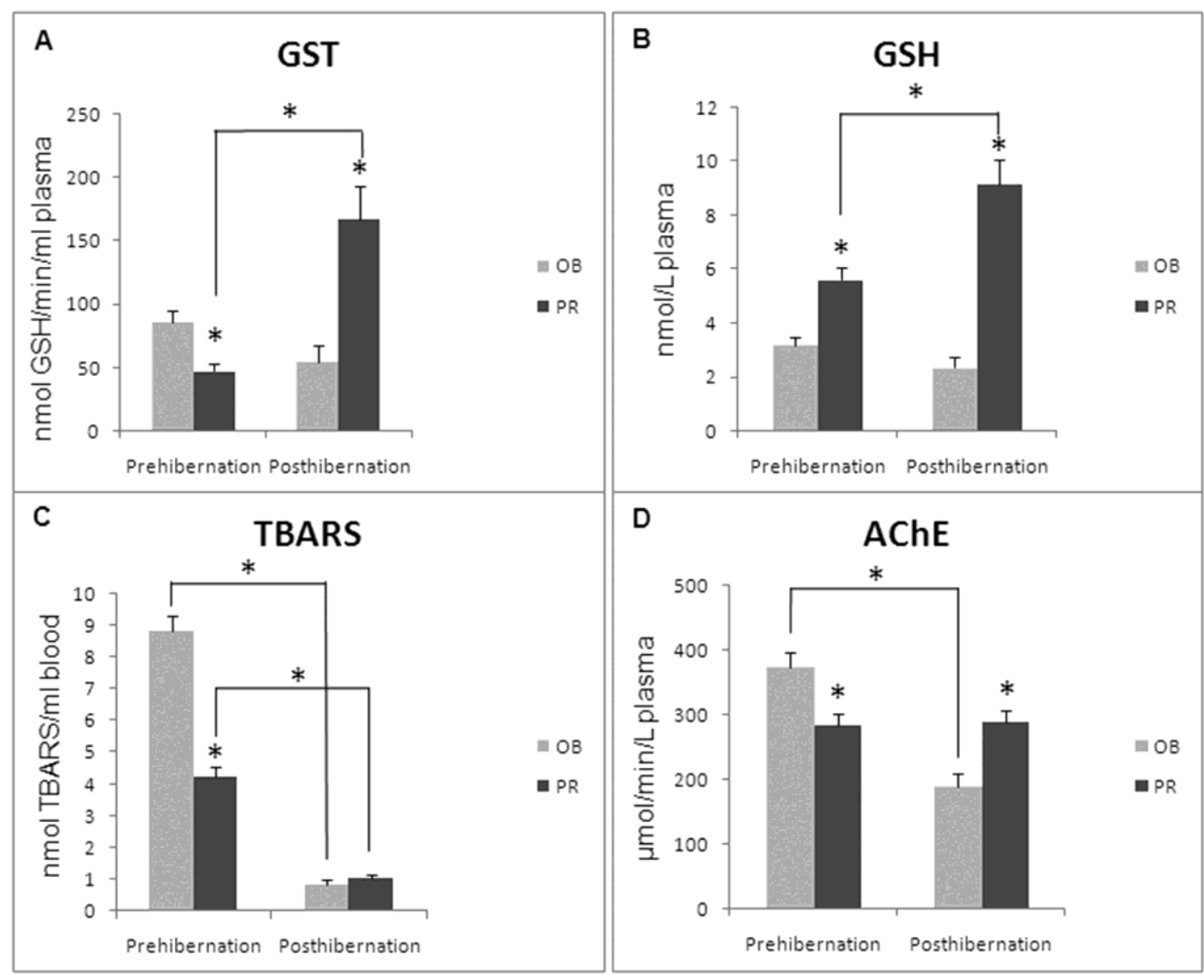

Figure 3 - Activity of A) plasma phase II biotransformation enzyme glutathione-S-transferase (GST; $\mathrm{U} / \mathrm{mL}$ plasma); B) plasma concentration of total glutathione (GSH; nmol/L plasma); C) blood concentration of lipid peroxides (TBARS; nmol/L blood); D) plasma acetylcholinesterase activity (AChE; U/L plasma) in the grass snake $N$. natrix from Obedska Bara (OB) and Pančevački Rit (PR) during the prehibernation and posthibernation periods. Significant differences between the means were established by the non-parametric Mann-Whitney U-test. $* \mathrm{p}<0.05$ represents a minimal significant level. 


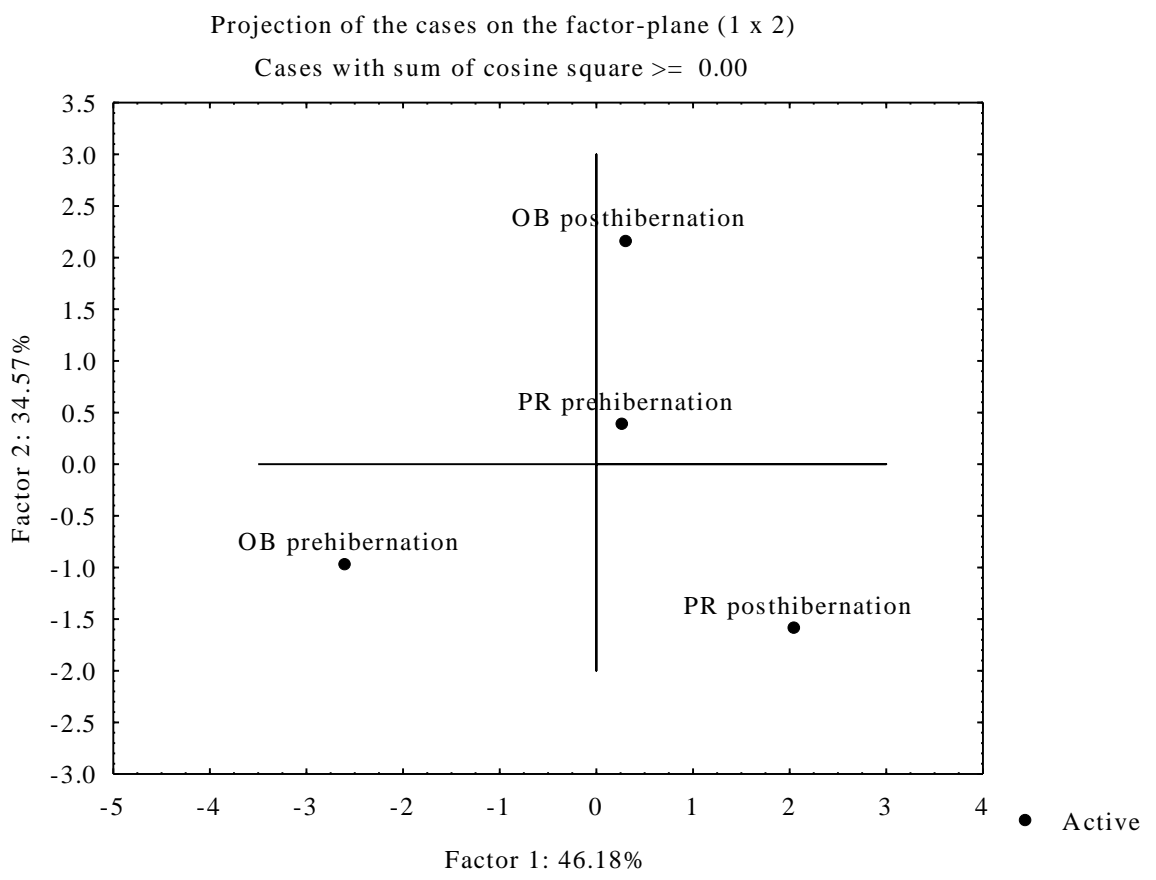

Figure 4 - Principal Component Analysis (PCA) of all of the investigated parameters: CuZn SOD, CAT, GSH-Px, GR, GST and AChE activities and GSH and TBARS concentrations in the blood of the grass snake N. natrix from the sites, The localities Obedska Bara (OB) and Pančevački Rit (PR) during the prehibernation and poshibernation periods are on the factor plane.

\section{DISCUSSION}

Hibernation is a prominent feature of the annual cycle in many reptiles, hence, prehibernation, hibernation and arousal from hibernation could be considered as the phases with specific, different demands for physiological and biochemical activities (El-Deib 2005). Since animals recovering from the hypometabolic state are exposed to increasing oxidative stress, they have developed mechanisms to prevent irreversible structural damage and maintain normal cell functions. Reperfusion in the animals adapted to anoxia/hypoxia or freezing is a physiological process that is an integral part of their natural life cycle (Orr et al. 2009). Pratihar et al. (2010) suggested that the high activity of antioxidant enzymes during hibernationwas an adaptive mechanism for preventing increased lipid peroxidation.

Data on antioxidant defence enzymes in the blood of the snakes during prehibernation and posthibernation are scarce, and comparisons between different animal groups need to be undertaken. Study on the changes of the antioxidant systems in Rana ridibunda during recovery from winter hibernation showed that the activity of the primary antioxidant defence enzymes, SOD and CAT, increased when the frogs were transferred to higher temperature (Bagnyukova et al. 2003). Because many reptile species could survive certain periods without $\mathrm{O}_{2}$, Hermes-Lima et al. (1993) hypothesized that reptile species contained a powerful antioxidant defence system capable of protecting these organisms from post-anoxic generation of excess amounts of ROS. Hermes-Lima and ZentenoSavín (2002) observed significant increases in the total-SOD in the muscle and liver of anoxiaexposed garter snakes, while these conditions generally did not have any effect on CAT activity. In this study, no significant difference in SOD activities before and after hibernation was observed at both the localities where the snakes were caught, but in posthibernating period, decrease of SOD activity at the PR in respect to OB was observed. Apparently the activity of SOD remained at a level capable of catalyzing the 
dismutation of the superoxide anion into oxygen and $\mathrm{H}_{2} \mathrm{O}_{2}$, and therefore, opposed the adverse effects of this free radical. According to the present results, CAT activity was higher at both the sites during the period before hibernation; however, statistical significance was only observed at the PR. There was a significant increase of CAT activity $(\mathrm{p}<0.05)$ at the PR in comparison to $\mathrm{OB}$ in prehibernating period. Salway et al. (2010) suggested that a relatively rapid up-regulation of MnSOD, GSH-Px and GR occurred early during arousal from the estivation of the Giant African snail (Achatina fulica). Gabryelak et al. (1983) who studied the enzymes involved in peroxide metabolism (SOD, CAT and GSH-Px) in the erythrocytes of freshwater fish species, detected higher activities in spring than in autumn.

The change in GSH-Px activity observed during different hibernating periods was not statistically significant. GR activity during the posthibernation period was significantly decreased in the snakes from $\mathrm{OB}$, whereas the snakes from the PR displayed an opposite pattern. According to Hayes and McLellan (1999), GR is one of the most important components of cellular protection against oxidative stress due to its ability to reduce oxidized glutathione using NADPH as a reductant. The level of GSH was significantly lower in the snakes from OB during both the periods, and was also significantly increased during the posthibernation period in the snakes from the PR. The elevation in GSH concentration probably protects from the oxidative stress that occurs during arousal (Avci et al. 2014). There was an increased concentration of GSH in the blood of grass snakes from the PR, a locality that was exposed to high anthropogenic pressure. GSH binds metals and prevents them from reacting with other biomolecules, and animal cells respond to contaminants by increasing the concentrations of this most abundant intracellular thiol (Olakolu et al. 2012). Metals such as $\mathrm{Cu}(\mathrm{II}), \mathrm{Co}(\mathrm{II}), \mathrm{Mn}(\mathrm{II})$, $\mathrm{Fe}(\mathrm{II})$ and $\mathrm{Cr}(\mathrm{VI})$ can react with $\mathrm{GSH}$, bringing about its oxidation (Christie and Costa 1984).

According to Kaisarevic et al. (2009), polychlorinated biphenyls (PCBs) and their methylated and alkylated derivatives are the major toxicants in the sediments of wastewater canals in the Pančevo industrial zone and surrounding area that is a well-known hot-spot of contamination. The phase II biotransformation enzyme GST catalyzes the binding of GSH with electrophilic substrates and is involved in the detoxification of a wide variety of chemicals (Eaton and Bammler 1999). Also, the secondary substrates for GST are toxic products generated by tissue damage (e.g., compounds resulting from lipid peroxidation of membranes). Several studies have shown that GST activity is increased in the brain of Rana pipiens (Hermes-Lima and Storey 1998) during anoxic exposure, and lowered in the kidneys and heart of $R$. sylvatica during freezing exposure (Joanisse and Storey 1996).

Lipid peroxidation often serves as an indicator of ROS-induced damage and it represents a very useful and sensitive biomarker (Abu Youssef et al. 2014). Willmore and Storey (1997) reported a decrease in TBARS level in the muscle of the freshwater turtle, Trachemys scripta elegans, after anoxic submersion. The present results showed a significant reduction of lipid peroxidation during the posthibernation period in the blood of the snakes from both the localities. Lower TBARS levels suggested that upon awakening, there was no oxidative damage of lipid molecules. Increased CAT and GSH-Px activities before hibernation could represent an adaptive response and a mechanism that prepared the organism for hibernation and increased ROS generation that occurred during arousal when the metabolic rate rapidly increased. Findings obtained from the studies of mammals have shown that the level of lipid peroxidation declined during late hibernation (Pratihar et al. 2010; Avci et al. 2014).

AChE is inhibited when organisms are exposed to organophosphate and carbamate pesticides (Srain and Rudolph 2010). Organophosphorus insecticides, carbamates, and organochlorine pesticides, pyrethroids, are potent $\mathrm{AChE}$ inhibitors (Robillard et al. 2003), and exposure to these chemicals elicits toxic effects that are usually sublethal (Amaral et al. 2012). In accordance with the fact that other chemicals, such as polycyclic aromatic hydrocarbons (Payne et al. 1996) and heavy metals (Bocquené et al. 1995) can also inhibit AChE, Lionetto et al. (2005) suggested that AChE was a very useful biomarker of the biological effect of a mixture of neurotoxic pollutants in the aquatic environment. There was inhibition of AChE activity in the blood of the snakes collected from $\mathrm{OB}$ in the spring (posthibernation period). In the snakes from the PR, AChE activity was almost the same during the investigated period. Several studies (Abdel-Halim et al. 2006; Chitmanat et al. 2008) have described 
the seasonal changes in $\mathrm{AChE}$ activity throughout the year, apparently linked with water temperature and the amount of precipitation.

Figure 4 shows the summary results of PCA for both the sampling localities. These showed that Factor 1 and Factor 2 explained over $80 \%$ of total variance. Regarding the position of the sites, Factor 1 (46.18\%) discriminated between OBprehibernation and OB-posthibernation/PRprehibernation/PR-posthibernation. Factor 2 (34.57\%) discriminated between OBprehibernation/PR-posthibernation and OBposthibernation/PR-prehibernation. Factor 1 showed clear separation between prehibernation and posthibernation periods at $\mathrm{OB}$, but no separation at the PR, suggesting different results of the investigated parameters at polluted locality. The results also showed clear separation of the analyzed parameters between prehibernation and posthibernation periods at both the localities (Factor 2).

\section{CONCLUSIONS}

In contrast to the great interest in mammalian hibernation, little is known about the role of the markers of the oxidative stress in reptile species, particularly in the snakes during preparation for hibernation and after arousal. In conclusion, the observed seasonal differences in the oxidative stress and neurotoxicity markers between prehibernation and posthibernation periods represented an adaptive mechanism to the oxidative stress that was induced by tissue reoxygenation during arousal from hibernation. Results also showed that external factors modulated both the biomarkers of oxidative stress and of neurotoxicity in the blood of the grass snake during the prehibernation and posthibernation periods.

\section{ACKNOWLEDGEMENTS}

This study was supported by the Ministry of Education, Science and Technological Development of Republic of Serbia, Grant No. 173041. The authors are grateful to Dr. Goran Poznanović for proofreading the manuscript.

\section{REFERENCES}

Abdel-Halim KY, Salama AK, El-Khateeb EN, Bakry NM. Organophosphorus pollutants (OPP) in aquatic environment at Damietta Governorate Egypt: Implications for monitoring and biomarker responses. Chemosphere. 2006; 63: 1491-1498.

Abu Youssef HA, Elshazly MI, Rashed LA, Sabry IM, Ibrahim EK. Thiobarbituric acid reactive substance (TBARS) a marker of oxidative stress in obstructive sleep apnea. Egypt J Chest Dis Tuberc. 2014; 63: 119-124

Amaral MJ, Sanchez-Hernandez JC, Bicho RC, Carretero MA, Valente R, Faustino AM, et al. Biomarkers of exposure and effect in a lacertid lizard (Podarcis bocagei Seoane) exposed to chlorpyrifos. Environ Toxicol Chem. 2012; 31: 2345-2353.

Andrews MT. Advances in molecular biology of hibernation in mammals. BioEssays. 2007; 29: 431440.

Avci E, Bulut S, Bircan FS, Ozluk A, Cevher SC. Effect of hibernation on oxidative and antioxidant events under laboratory conditions in Anatolian Ground Squirrel, Spermophilus xanthoprymnus (Bennett, 1835) (Mammalia: Sciuridae) from Central Anatolia. Pakistan J Zool. 2014; 46: 177-183.

Bagnyukova TV, Storey KB, Lushchak VI. Induction of oxidative stress in Rana ridibunda during recovery from winter hibernation. J Therm Biol. 2003; 28: 2128.

Bartoskova M, Dobsikova R, Stancova V, Zivna D, Blahova J, Marsalek P, Zelníckova L, et al. Evaluation of ibuprofen toxicity for zebrafish (Danio rerio) targeting on selected biomarkers of oxidative stress. Neuro Endocrinol Lett. 2013; 34: 102-108.

Bauwens D. Survivorship during hibernation in the European Common Lizard, Lacerta vivipara. Copeia. 1981; 1981: 741-744.

Bocquené G, Bellanger C, Cadiou Y, Galgani F. Joint action of combinations of pollutants on the acetylcholinesterase activity of several marine species. Ecotoxicology. 1995; 4: 266-279.

Campbell KR, Campbell TS. The accumulation and effects of environmental contaminants on snakes: a review. Environ Monit Assess. 2001; 70: 253-301.

Chitmanat C, Prakobsin N, Chaibu P, Traichaiyaporn S. The use of acetylcholinesterase inhibition in River Snails (Sinotaia ingallsiana) to determine the pesticide contamination in the upper Ping River. Int $J$ Agri Biol. 2008; 10: 658-660.

Christie NT, Costa M. In vitro assessment of the toxicity of metal compounds. IV. Disposition of metals in cells: Interactions with membranes, glutathione, metallothioneins and DNA. Biol Trace Elem Res. 1984; 6: 139-158. 
Claiborne A. Catalase activity. In: Greenwald RA, editor. Handbook of Methods for Oxygen Radical Research. Boca Raton, FL: CRC Press; 1984. p. $283-$ 284.

Darlington RB, Weinberg SL, Walberg HJ. Canonical variate analysis and related techniques. Rev Educ Res. 1973; 43: 433-454.

Dinneen LC, Blakesley BC. A generator for the sampling distribution of the Mann-Whitney $U$ statistic. Appl Stat. 1973; 22: 269-273.

Drabkin DL, Austin, JH. Spectrophotometric studies: II. preparations from washed blood cells; nitric oxide hemoglobin and sulfhemoglobin. J Biol Chem. 1935; 112: 51-65.

Durieux EDH, Farver TB, Fitzgerald PS, Eder KJ, Ostrach D.J. Natural factors to consider when using acetylcholinesterase activity as neurotoxicity biomarker in Young-Of-Year striped bass (Morone saxatilis). Fish Physiol Biochem. 2011; 37: 21-29.

Eaton DL, Bammler T.K. Concise review of the glutathione S-transferases and their significance to toxicology. Toxicol Sci. 1999; 49: 156-164.

El-Deib S. Lipid changes in blood serum and tissues of the Egyptian Cobra "Naja haje haje" during the hibernation cycle. J Therm Biol. 2005; 30: 51-59.

Ellman GL, Courtney KD, Andres VJr, Featherstone R.M. A new and rapid colorimetric determination of acetylcholinesterase activity. Biochem Pharmacol. 1961; 7: 88-95.

Fazio F, Cecchini S, Faggio C, Caputo AR, Piccione G. Stability of oxidative stress biomarkers in flathead mullet, Mugil cephalus, serum during short-term storage. Ecological Indicators. 2014; 46: 188-192.

Gabryelak T, Piatkowska M, Leyko W, Pérès G. Seasonal variations in the activities of peroxide metabolism enzymes in erythrocytes of freshwater fish species. Comp Biochem Physiol C. 1983; 75: 383-385.

Glatzle D, Vuilleumier JP, Weber F, Decker K. Glutathione reductase test with whole blood, a convenient procedure for the assessment of the riboflavin status in humans. Experientia. 1974; 30: 665-667.

Gregory PT, Isaac LA. Food habits of the Grass Snake in southeastern England: Is Natrix natrix a generalist predator? J Herp. 2004; 38: 88-95.

Griffith OW. Determination of glutathione and glutathione disulfide using glutathione reductase and 2-vinylpyridine. Anal Biochem. 1980; 106: 207-212.

Habig WH, Pabst MJ, Jakoby WB. Glutathione Stransferases. The first enzymatic step in mercapturic acid formation. J Biol Chem. 1974; 249: 7130-7139.

Hayes JD, McLellan LI. Glutathione and glutathionedependent enzymes represent a co-ordinately regulated defence against oxidative stress. Free Radic Res. 1999; 31: 273-300.
Hermes-Lima M, Storey KB. Role of antioxidant defenses in the tolerance of severe dehydration by anurans. The case of the leopard frog Rana pipiens. Mol Cell Biochem. 1998; 189: 79-89.

Hermes-Lima M, Zenteno-Savín T. Animal response to drastic changes in oxygen availability and physiological oxidative stress. Comp Biochem Physiol C. 2002; 133: 537-556.

Hermes-Lima M, Storey KB. Antioxidant defenses in the tolerance of freezing and anoxia by garter snakes. Am J Physiol. 1993; 265: 646-652.

Hopkins WA. Reptile toxicology: challenges and opportunities on the last frontier in vertebrate ecotoxicology. Environ Toxicol Chem. 2000; 19: 2391-2393.

Joanisse DR, Storey KB. Oxidative damage and antioxidants in Rana sylvatica, the freeze-tolerant wood frog. Am J Physiol. 1996; 271: 545-553.

Kaisarevic S, Varel UL, Orcic D, Streck G, Schulze T, Pogrmic K, et al. Effect-directed analysis of contaminated sediment from the waste water canal in Pancevo industrial area, Serbia. Chemosphere. 2009; 77: 907-913.

Kovačević TB, Borković SB, Pavlović SZ, Despotović SG, Saičić ZS. Glutathione as a suitable biomarker in hepatopancreas, gills and muscle of three freshwater crayfish species. Arch Biol Sci Belgrade. 2008; 60: 59-66.

Lionetto MG, Caricato R, Giordano M, Schettino T. Acetylcholinesterase as biomarker in environmental biomonitoring. In: Parveen M, Kumar S, editors. Recent Trends in the Acetylcholinesterase System. Amsterdam, Washington DC: IOS Press; 2005. p. 91102.

Maral J, Puget K, Michelson AM. Comparative study of superoxide dismutase, catalase and glutathione peroxidase levels in erythrocytes of different animals. Biochem Biophys Res Commun. 1977; 77: 1525-1535.

McCord JMC, Fridovich I. Superoxide dismutase. An enzymic function for erythrocuprein (hemocuprein). $J$ Biol Chem. 1969; 244: 6049-6055.

Messina CM, Faggio C, Laudicella VA, Sanfilippo M, Trischitta F, Santulli A. Effect of sodium dodecyl sulfate (SDS) on stress response in the Mediterranean mussel (Mytilus galloprovincialis): Regulatory volume decrease (Rvd) and modulation of biochemical markers related to oxidative stress. Aquatic Toxicol. 2014; 157: 94-100.

Misra HP, Fridovich I. The role of superoxide anion in the autoxidation of epinephrine and a simple assay for superoxide dismutase. J Biol Chem. 1972; 247: 31703175.

Ohkawa H, Ohishi N, Yagi K. Assay for lipid peroxides in animal tissues by thiobarbituric acid reaction. Anal Biochem. 1979; 95: 351-358. 
Olakolu FC, Hassan AA, Renner KO. Lipid peroxidation and antioxidant biomarker activities as indicator of pollution in Blue Crab Callinectes amnicola from Lagos lagoon. Br J Sci. 2012; 5: 4756.

Orr AL, Lohse LA, Drew KL, Hermes-Lima M. Physiological oxidative stress after arousal from hibernation in Arctic ground squirrel. Comp Biochem Physiol A. 2009; 153: 213-221.

Pavlović SZ, Borković Mitić SS, Radovanović TB, Perendija BR, Despotović SG, Gavrić JP, et al. Seasonal variations of the activity of antioxidant defence enzymes in the red mullet (Mullus barbatus L.) from the Adriatic Sea. Mar Drugs. 2010; 8: 413428.

Payne JF, Mathieu A, Melvin W, Fancey LL. Acetylcholinesterase, an old biomarker with a new future? Field trials in association with two urban rivers and a paper mill in Newfoundland. Mar Poll Bull. 1996; 32: 225-231.

Pratihar S, Sen S, Bhattacharya T. Antioxidant activity and lipid peroxidation status during the period of hibernation in Indian Pond Frog, Euphlytes hexadactyla Lesson, 1834. Russ J Herpetol. 2010; 17: 101-104.

Robillard S, Beauchamp G, Laulier M. The role of abiotic factors and pesticide levels on enzymatic activity in the freshwater mussel Anodonta cygnea at three different exposure sites. Comp Biochem Physiol C. 2003; 135: 49-59.
Salway KD, Tattersall GJ, Stuart JA. Rapid upregulation of heart antioxidant enzymes during arousal from estivation in the Giant African snail (Achatina fulica). Comp Biochem Physiol A. 2010; 157: 229-236.

Srain B, Rudolph A. Acetylcholinesterase activity, antioxidant defenses, and lipid peroxidation in the clam Semele solida: Can this species be used as a bioindicator? Rev Biol Mar Oceanogr. 2010; 45: 227 233.

Storey KB, Storey J.M. Metabolic rate depression and biochemical adaptation in anaerobiosis, hibernation and estivation. $Q$ Rev Biol. 1990; 65: 145-174.

Thapliyal JP, Sharan S. Seasonal variation in the oxygen consumption of tissues in the water snake Natrix piscator with special reference to hibernation. Indian J Exp Biol. 1980; 18: 236-239.

Tsuchihashi M. Zür Kenntnis der Blutkatalase. Biochem Z. 1923; 140: 65-74.

Valko M, Leibfritz D, Moncol J, Cronin MT, Mazur M, Telser J. Free radicals and antioxidants in normal physiological functions and human disease. Int $J$ Biochem Cell Biol. 2007; 39: 44-84.

Van der Oost R, Beyer J, Vermeulen NP. Fish bioaccumulation and biomarkers in environmental risk assessment: a review. Environ Toxicol Pharmacol. 2003; 13: 57-149.

Willmore WG, Storey KB. Glutathione systems and anoxia tolerance in turtles. Am J Physiol. 1997; 273: 219-225. 